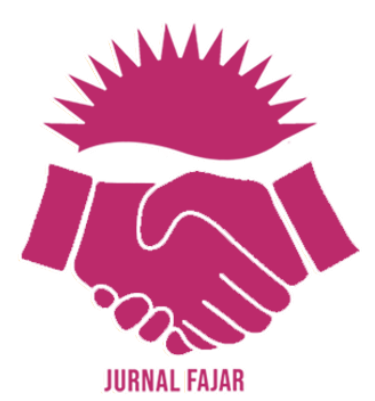

\title{
Pendampingan Hukum PenyalahgunaAn Media Sosial DI SMAN 2 KOTA SERANG*
}

\author{
Wicipto Setiadiı, Beniharmoni Harefa, Heru Suyanto, \\ Martina Indirarosa \\ Universitas Pembangunan Nasional Veteran Jakarta \\ E-mail: wiciptos@gmail.com
}

\subsection{8/jf.v21i1.20328}

\begin{abstract}
:
The development of information and technology, has a positive impact on human life, but on the other, it will have a negative impact. The misuse of social media, especially in the school, is an important thing to pay attention to. This paper aims to provide understanding and legal assistance in order to avoid misuse of social media. The first step taken was to provide socialization and enlightenment to the students and the school, especially SMAN 2 Kota Serang about the dangers of misuse of social media. Understanding and enlightening students about the dangers of misuse of social media is an effort to prevent the occurrence of misuse of social media, especially in the school. The results and impact of the implementation of program can be seen in the understanding of students and schools regarding the dangers of misuse of social media.
\end{abstract}

Keywords: legal protection, UU ITE, student.

* Diterima 18 November 2020, Revisi 5 Desember 2020, Diterbitkan 30 Januari 2021.

Fajar: Media Komunikasi dan Informasi Pengabdian Kepada Masyarakat Vol 21 No 1 (2021) - 57 


\section{Abstrak:}

Perkembangan informasi dan teknologi disatu sisi memberikan dampak positif bagi kehidupan manusia, namun disisi lain akan memberikan dampak negatif. Penyalahgunaan media sosial khususnya dilingkungan sekolah menjadi hal penting untuk diperhatikan. Tulisan ini bertujuan untuk memberikan pemahaman dan pendampingan hukum guna menghindari penyalahgunaan media sosial. Langkah pertama yang dilakukan adalah memberikan sosialisasi dan pencerahan kepada para siswa dan pihak sekolah khususnya SMAN 2 Kota Serang akan bahaya penyalahgunaan media sosial. Pemahaman dan pencerahan kepada para siswa akan bahaya penyalahgunaan media sosial menjadi upaya pencegahan (preventif) terjadinya penyalahgunaan media sosial khususnya di lingkungan sekolah. Hasil dan dampak pelaksanaan kegiatan terlihat pada pemahaman siswa dan pihak sekolah pada bahaya penyalahgunaan media sosial.

Kata kunci: perlindungan hukum, UU ITE, siswa. 


\section{Pendahuluan}

Teknologi informasi mengalami perkembangan dengan munculnya internet dan diikuti dengan hadirnya media sosial. Media sosial merupakan media yang memungkinkan setiap berinteraksi maupun bersosialisasi dan berkomunikasi tanpa terhalang ruang dan waktu.[1] Dimensi kedaulatan negara pun meluas, tidak lagi terdiri dari wilayah daratan, lautan, dan ruang-udara, melainkan juga ruang-maya. Ruang maya ini memunculkan aksi-aksi kejahatan dimensi baru, yang menggunakan media internet (cybercrime).

Indonesia telah memiliki Undang-Undang Nomor 11 Tahun 2008 tentang Informasi dan Transaksi Elektronik.[2] Penanggulangan kejahatan di dunia maya tentunya membutuhkan terobosan hukum yang tidak lagi hanya menggunakan hukum konvensional namun menggunakan desain hukum yang dinamis yang dapat mengakomodir perkembangan zaman.

Ruang-maya yang tercitra dari internet telah menciptakan suatu rezim hukum baru yang dikenal dengan hukum internet (the law of the internet), hukum ruang-maya (cyberspace law), atau hukum telematika. Hukum mayantara dan tindak pidana yang berkaitan dengan hukum disebut sebagai tindak pidana mayantara.[3] Berbagai hal terkait kejahatan dunia maya diatur melalui UndangUndang Nomor 11 Tahun 2008 tentang Informasi dan Transaksi Elektronik sebagaimana telah diperbaharui melalui Undang-Undang Nomor 19 Tahun 2016 tentang Perubahan Atas Undang-Undang Nomor 11 Tahun 2008 tentang Informasi dan Transaksi Elektoronik.

Pengaturan tersebut termasuk di dalamnya yakni penggunaan media sosial. Media sosial acapkali dipergunakan pihak-pihak tidak bertanggungjawab untuk hal-hal yang tidak diinginkan. Jaringan media sosial seperti friendster, facebook, my space, twitter, you tube, instagram, BlackBerry Masseger (BBM), Line, Path, ternyata memiliki posisi yang sangat penting yaitu dapat menjadi mekanisme menghimpun aksi, protes, dan gerakan sosial masyarakat atau publik dapat berpartisipasi langsung dan sharing informasi dengan pihak-pihak yang dipercaya seperti teman dan keluarga.[4] Media sosial dapat digunakan untuk membantu kehidupan manusia, namun demikian dapat juga memberikan dampak buruk dan negatif.

Sebagian pengguna sosial media menggunakan media tersebut dengan tidak bijak, seperti halnya menyebarkan berita hoax, penipuan, pornografi, dan lainnya. Hal ini yang membuat bersosial media di media sosial sangat berbahaya karena ada remaja dan anak-anak yang menggunakan sosial media untuk berinteraksi sesama penggunanya.[5] Hal-hal ini dapat berdampak buruk bagi kehidupan khususnya anak-anak, remaja-remaja sebagai generasi penerus bangsa. Hal ini menjadi salah satu yang melandasi pemikiran untuk melakukan pengabdian kepada masyarakat guna meningkatkan pemahaman khususnya anak dan remaja 
di lingkungan sekolah terkait penggunaan media sosial agar tidak disalahgunakan.

Perkembangan teknologi informasi dapat meningkatkan kinerja dan produktivitas karena memungkinkan melakukan berbagai kegiatan dengan cepat, tepat dan akurat. Hal ini juga berakibat pada tidak adanya batas suatu wilayah (borderless).[6] Hal ini terasa ketika menggunakan media sosial, dalam waktu yang tidak terlalu lama kita dapat berkomunikasi dengan cepat dengan orang lain, dan dapat menyampaikan berita, informasi dan hal-hal lainnya.

Dewasa ini internet hanyalah momok bagi sejumlah Negara yang membatasi akses internet warga negaranya. Beberapa negara di kawasan Asia, Afrika dan Timur Tengah memberlakukan restriksi ketat di internet. Di Suriah, seorang narablog ditangkap ketika hendak menghadiri konferensi di Yordania. Pemerintah Iran juga kerap kali memblokir situs-situs-web berbahasa Inggris seperti BBC dan Voice of America, mengalihkan perambanan ke situs-situs-web yang memuat nilai-nilai revolusi Iran.[7] Hal ini dapat dipahami agar keutuhan suatu bangsa dan Negara tetap dapat terjaga, mengingat penyalahgunaan internet yang sudah tidak mengenal ruang dan waktu.

Beberapa hal sering sekali terlambat diakomodir dan diatur melalui hukum, hal ini dapat diakibatkan perkembangan dinamika teknologi yang pesat. Kekosongan hukum ini tentu saja membawa implikasi terhadap perlindungan privasi dan data pribadi.[8] Beberapa hal diantaranya yang menjadi kejahatan melalui media online, banyak yang belum diakomodir oleh aturan perundangundangan. Sehingga hukum sering sekali ketinggalan dibandingkan dengan perkembangan itu sendiri.

Di Indonesia, internet memiliki pertumbuhan dan perkembangan yang sangat pesat. Meski dari segi persentase sebaran dan penetrasi populasi internet masih rendah, Indonesia adalah salah satu negara dengan jumlah pengguna internet terbesar di Asia Tenggara. Warung Internet (warnet), mulai tersedia dan menjamur pada 1998 di pelbagai kota besar di Indonesia kendati akses internet pada kurun waktu 1998-2000 masih merupakan sebuah kemewahan untuk sebagian besar masyarakat.[9] Di Indonesia internet sudah dinikmati dari berbagai kalangan dari anak kecil hingga kalangan dewasa.

Media sosial selain memberikan dampak positif, dapat juga disalahgunakan oleh oknum tidak bertanggung jawab, media sosial dapat menimbulkan persoalan.[10] Penyalahgunaan ini seandainya dilakukan oleh anak dan remaja terutama yang berada di lingkungan sekolah akan menjadi persoalan yang dapat memiliki dampak hukum terhadap anak dan remaja.

Kalangan anak dan remaja khususnya yang dudukan dibangku sekolah tentunya tidak asing dengan media sosial. Pengguna media sosial seperti facebook agar lebih bijaksana dan menjaga etika agar tidak menimbulkan persoalan hukum.[11] Penyalahgunaan media sosial seperti facebook membuka peluang 
bagi kejahatan dunia maya.[12] Diperlukan pencegahan sejak dini agar anak-anak dan remaja khususnya yang duduk dibangku sekolah tidak terjebak dan terjurumus hingga menyalahgunakan media sosial.

Sekolah Menengah Atas Negeri 2 Kota Serang menjadi wilayah yang dipilih untuk mensosialisasikan bahaya penggunaan media sosial tanpa batas. Pemilihan ini dilakukan dengan pertimbangan bahwa masyarakat sekolah menjadi pihak rentan terkena penyalahgunaan internet khususnya media sosial. Baik guru maupun siswa serta seluruh pihak yang berada di sekolah sebaiknya mengerti dan paham akan dampak buruk dan dampak negatif dari media sosial jika tidak dikelola dengan baik.

Khusus penyalahgunaan media sosial di lingkungan sekolah, akan diulas dalam tulisan ini. Mengingat sering terjadi pro dan kontra terkait penyalahgunaan media sosial, disatu sisi perkembangan informasi dan teknologi sangat membantu siswa dalam hal mengakses pelajaran, namun disisi lain perkembangan teknologi dan informasi juga dapat merusak dan memiliki dampak negatif apabila disalahgunakan termasuk penggunaan media sosial.

Oleh sebab itu, melalui pelaksanaan penyuluhan ini diharapkan memberikan pemahaman kepada para siswa dan seluruh pihak yang berada khususnya lingkungan sekolah, bahwa media sosial memiliki bahaya dan dampak negatif serta telah diatur di dalam aturan perundang-undangan. Setiap orang yang menyalahgunakan akan dikenai sanksi, sanksi berupa sanksi pidana denda hingga sanksi pidana penjara. Melalui pemahaman ini diharapkan sebagai upaya preventif (pencegahan) di masa mendatang, agar siswa dan seluruh pihak tidak menyalahgunakan media sosial.

Adapun yang menjadi identifikasi masalah dari pengabdi sebelum melaksanakan pengabdian ini adalah: maraknya pelanggaran UU ITE di lingkungan sekolah, kurangnya pemahaman tentang pelanggaran UU ITE. Bagaimana memberikan kesadaran hukum kepada masyarakat terutama di lingkungan sekolah untuk mempunyai kemampuan memahami dan mengerti bahaya pelanggaran UU ITE di lingkungan sekolah serta dampak hukumnya.

Kegiatan pengabdian ini dilaksanakan dengan tujuan untuk menumbuhkan kesadaran hukum masyarakat terutama sebagai upaya pencegahan penyalahgunaan media sosial di lingkungan sekolah. Memberdayakan seluruh pemangku kepentingan di sekolah untuk melakukan pencegahan dari penyalahgunaan media sosial di lingkungan sekolah. Khalayak sasaran yang strategis dalam kegiatan ini adalah lingkungan sekolah di SMAN 2 Kota Serang.

Dalam rangka mencapai tujuan yang tercantum diatas, maka ditempuh langkah-langka sebagai berikut : Menghubungi Kepala Sekolah SMAN 2 Kota Serang untuk membahas topik yang akan disampaikan dalam penyuluhan. Menyelenggarakan kegiatan penyuluhan kesadaran hukum dan simulasi serta pembentukan kelompok pendeteksi pelanggaran UU ITE. 
Pengabdian Masyarakat ini khalayak sasarannya adalah kalangan anak dan remaja yang merupakan kelompok masyarakat yang dianggap potensial untuk menjadi agen dan garda paling depan dalam pencegahan penyalahgunaan media sosial di lingkungan sekolah. Mitra ini ditetapkan dengan mempertimbangkan efisiensi dan intensitas pelaksanaan program. Anak dan remaja dianggap sebagai orang yang paling dekat dan rentan menjadi sasaran penyalahgunaan media sosial di lingkungan sekolah. Hasil Pengabdian Kepada Masyarakat ini juga akan dipublikasikan pada Jurnal atau Prosiding.

\section{Metode}

Kegiatan pengabdian masyarakat ini dilaksanakan dengan metode penyuluhan dan diskusi, simulasi dengan khalayak sasaran yaitu siswa sekolah dan guru-guru di lingkungan SMAN 2 Kota Serang. Oleh karena situasi pandemic COVID-19, maka kegiatan dilaksanakan melalui online dengan menggunakan aplikasi zoom cloud meeting. Untuk rangka mencapai tujuan yang tercantum diatas, maka ditempuh langkah-langka sebagai berikut : Pertama, tahap persiapan yaitu: a) Proses Perizinan kepada pihak mitra dengan menghubungi Kepala SMAN 2 Kota Serang untuk membahas topik yang akan disampaikan dalam penyuluhan; b) Proses pengumpulan data. Kedua, tahap pelaksanaan yakni kegiatan pelatihan dengan khalayak sasaran dan diskusi dengan mitra mengenai analisa dan solusi. Keempat, tahap monitoring dan evaluasi.

\section{Hasil dan Pembahasan}

Kegiatan telah terlaksana pada bulan Juni 2020. Melalui kegiatan pengabdian kepada masyarakat, maka pihak-pihak sekolah khususnya di SMAN 2 Kota Serang mulai dari Kepala Sekolah, Guru-guru, Siswa, Karyawan sekolah, memahami dan sadar akan rentannya sekolah menjadi lingkungan yang menjadikan anak sebagai korban kekerasan.

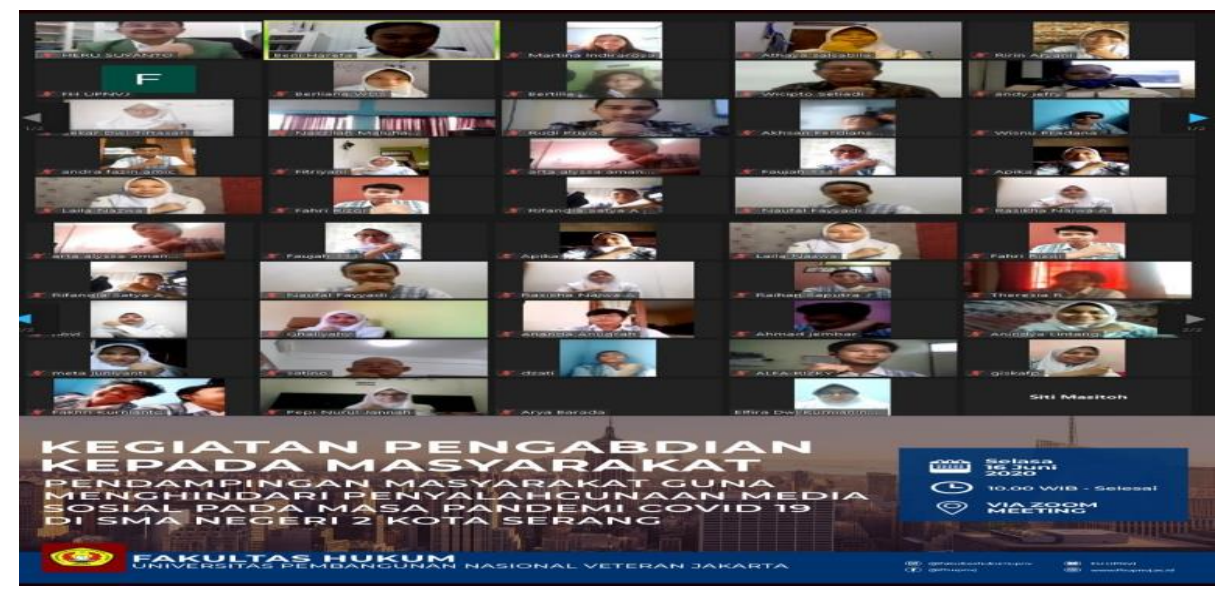

Gambar.1.1 Pelaksanaan Kegiatan Pendampingan Hukum Penyalahgunaan Media Sosial. 
Kegiatan dilaksanakan melalui media Zoom Cloud Meeting yang dilakukan untuk meningkatkan kesadaran hukum khusunya dari pihak sekolah akan penyebab, bahaya dan penanggulangan penyalahgunaan media sosial yang terjadi di lingkungan sekolah. Hasil kegiatan pengabdian kepada masyarakat ini ternyata telah memberikan dampak yang sangat signifikan terhadap perkembangan pengetahuan dan pemahaman masyarakat khususnya akan bahaya penyalahgunaan media sosial. Sebagaimana kita ketahui bersama di era kemajuan informasi dan teknologi maka berbagai dampak positif dan negatif dapat terjadi. Untuk menghindari dampak negatif termasuk penyalahgunaan media sosial, maka perlu penjelasan dan pemahaman masyarakat terkait bahaya penyalahgunaan media sosial dan bagaimana hukum mengatur terkait hal dimaksud.

Hasil dan dampak pelaksanaan kegiatan terlihat pada pemahaman siswa dan pihak sekolah pada bahaya penyalahgunaan media sosial. Hal ini diketahui setelah pelaksanaan kegiatan, para pengabdi melakukan evaluasi dengan menyebarkan kuisioner dan terlihat hasil bahwa para siswa serta pihak di lingkungan sekolah, memahami arti penting media sosial dan dampak buruk apabila menyalahgunakan media sosial, serta sanksi hukum hingga sanksi pidana penyalahgunaan media sosial.

\section{Kesimpulan}

Peserta mendapatkan manfaat dari kegiatan pengabdian masyarakat yang dilakukan. Saran di masa mendatang, agar sosialisasi terhadap aturan hukum terkait penyalahgunaan media sosial semakin ditingkatkan. Masyarakat yang menjadi sasaran tidak hanya di lembaga pendidikan. Namun, di lembaga keagamaan, di kelurahan, di desa-desa, dan tempat-tempat lainnya. Hal ini disebabkan masih tingginya tingkat pelanggaran dn penyalahgunaan media sosial yang terjadi.

\section{Referensi}

[1] F. Y, "Analisis Pemanfaatan Berbagai Media Sosial Sebagai Sarana Penyebaran Informasi Bagi Masyarakat," Jurnal Paradigma, vol. 19, No. 2, doi: 10.31294/p.v19i2.2120.

[2] R. A, "Menganalisis Kesiapan Indonesia Dalam Penanggulangan dan Penegakan Hukum Kejahatan Global Berbasis Internet Berdasarkan UndangUndang Informasi dan Transaksi Elektronik," Prosiding Seminar Nasional INDOCOMPAC, 2016.

[3] A. BN, Tindak Pidana Mayantara: Perkembangan Kajian Cyber Crime di Indonesia. Jakarta: Raja Grafindo Persada, 2006.

[4] D. RA, "Penegakan Hukum Pidana Terhadap Penyebaran Berita Bohong di Sosial Media," vol. 4, No. 2, 2019, doi: 10.21067/jph.v4i2.3902. 
64 - Wicipto Setiadi, Beniharmoni Harefa, Heru Suyanto, Martina Indirarosa

[5] N. CA, "Peningkatan Pemahaman Undang-Undang Informasi Teknologi Nomor 19 Tahun 2016 tentang Media Sosial Kepada Siswa di SMPN 42 Kota Medan," Jurnal Pengabdian Kepada Masyarakat, vol. 2, No. 1, 2021, doi: 10.46576/rjpkm.v2i1.643.

[6] K. L, "Perlindungan Hukum Data Pribadi Terhadap Penyalahgunaan Data Pribadi Pada Platform Media Sosial," Jurnal Hukum De'rechtsstaat, vol. 6, No. 2, 2020, doi: 10.30997/jhd.v6i2.2676.

[7] A. Ap E, "Kedaulatan Negara di Ruang Maya: Kritik UU ITE Dalam Pemikiran Satjipto Rahardjo," Gema Keadilan, vol. 1, No. 1, hlm. 78-108, 2014, doi: 10.3592/2.

[8] R. SD, "Konsep Perlindungan Hukum Atas Privasi dan Data Pribadi Dikaitkan Dengan Penggunaan Cloud Computing di Indonesia," Jurnal Yustisia Hukum, vol. 5, No. 1, 2016, doi: 10.20961/yustisia.v0i94.2780.

[9] B. FK, "Warnet, Riwayatmu Dulu dan Sekarang," 2015. https:/tekno.kompas.com/read/2015/04/22/13140077/Warnet.Riwayatmu.Dulu .dan.Sekarang?page=all (diakses Jan 22, 2020).

[10]L. TM dan dkk, "Penyuluhan Hukum Dampak Media Sosial Bagi Remaja," Jurnal Abdimas Talenta, vol. 4, No. 1, 2019, doi: 10.46576/rjpkm.v1i1.534.

[11]R. M dan dkk, "Waspada Cybercrime dan Informasi Hoax Pada Media Sosial Facebook," Jurnal Ilmu Perpustakaan Informasi dan Kearsipan, vol. 6, No. 2, hlm. 98-111, 2016, doi: 10.24252/kah.v6i2a2.

[12]J. L dan dkk, "Analisa Pola Penyalahgunaan Facebook Sebagai Alat Kejahatan Trafficking Menggunakan Data Mining," Jurnal Teknik Informatik, vol. 8, No. 1, doi: 10.35793/jti.8.1.2016.12231. 